\title{
Protein metabolism after surgery
}

\section{By A. Fleck, Department of Chemical Pathology, Charing Cross Hospital Medical School, London W6 8RF}

The development of studies on protein metabolism after injury

Munro (1964) has reviewed the development of the experimental study of protein metabolism in man, which began 140 years ago with Mulder's $\left(183^{8}\right)$ introduction of the word protein (from $\pi \rho \omega t \varepsilon l 0 S$, primarius) at Berzelius' suggestion (Almqvist \& Wiksell, 1916) and Bousingault's (1839a,b) nitrogen balance studies on a milk cow and a horse. A few years later Vogel (1854) using Liebig's new method of determining urea in urine demonstrated that during typhoid fever the urea output in the urine in $24 \mathrm{~h}$ was greater than when the patient had recovered a few weeks later. Several studies confirming this increased output of $\mathrm{N}$ in the urine during fever and demonstrating the effects of therapy followed. Examples include Sassetzky's (1883) study of the antipyretic effect of hydrotherapy, Muller's ( $\mathbf{~ 8 8 4}_{4}$ ) demonstration of the prompt beneficial effect of antipyrin and the detailed study by Shaffer \& Coleman (1909) in which they found that adequate intake of energy and protein could prevent the negative $\mathrm{N}$ balance of typhoid fever.

The holocaust of the First World War prompted collaborative studies of the effects of severe injury and shock on metabolism. In a series of studies Wertheimer et al. (1919) observed that increased excretion of urea in urine persisted for some time and attained outputs of 40 to $57 \mathrm{~g} / \mathrm{d}$. They concluded that this represented a considerable increase in the breakdown of body protein. In studies of patients who had suffered burning injuries Davidson (1926) reported that there was an increase of $\mathrm{N}$ excretion in the urine and concluded that there was evidence of increased protein catabolism.

It has been recognized for some time that Cuthbertson's (1932) studies of metabolism in patients after accidental fractures of long bones and orthopaedic operations (see Fleck, 1978) began the modern era of studies in injury metabolism. He showed clearly that after injury or surgery there was an increase in the excretion of $\mathrm{N}$ in the urine which reached a maximum around the 4th to 6 th $\mathrm{d}$ and that there were parallel increases in urine phosphate, sulphate, body temperature, pulse rate and basal metabolic rate (BMR) even in the absence of infection. Later, in a prize lecture, Cuthbertson (1942) introduced the concept of the ebb and flow phases of the response to injury. The ebb phase roughly corresponds to clinical shock which may deteriorate and become irreversible (necrobiosis; Stoner, 1970), or may progress to the flow phase which consists of an early or catabolic phase and a later recovery or anabolic phase (Moore, 1953). 


\section{Current concepts}

At present it is widely accepted that there are at least ten main factors which influence metabolism after injury or surgery.

\section{Primary factors}

The extent and nature of the injury. An early illustration of the influence of the extent of the injury on nitrogen excretion is that of Moore et al. (r955) in which they showed that minor elective surgery such as repair of a simple hernia led to almost no change in $\mathrm{N}$ balance while major surgery led to a large cumulative negative $\mathrm{N}$ balance which correlated closely with the increase in excretion of 17-hydroxycorticosteroids in the urine. Later Kinney et al. (1970) extended this, showing that the increasing effect on resting metabolic energy expenditure (RME) and hence $\mathbf{N}$ excretion were in the following order: elective surgery, multiple injuries, sepsis and minor burns. The last could give rise to increases in RME of r $00 \%$ or more.

Infection. The occurrence of increased $\mathrm{N}$ excretion in infection and sepsis has been mentioned above. Next to severe burns, sepsis seems to result in the greatest loss of body protein following injury. In collaborative studies in Glasgow Western Infirmary we have observed increases in urinary $N$ excretion to $30^{\circ}-35 \mathrm{~g} / \mathrm{d}$ in severe sepsis.

Stress. Stress alone, that is unaccompanied by tissue damage, because of the related increased excretion of the catecholamines (adrenalin and noradrenalin) would be expected to lead to net protein catabolism (Granitsas, 1960), and hence increased excretion of $\mathbf{N}$ in the urine. In preliminary observations we have confirmed this (Fleck et al. 1979).

Pain. Masek \& Horky (1957) have reported negative $\mathrm{N}$ balance in patients suffering chronic pain. Relief of the pain without influencing the underlying disease led to improvement in the $\mathrm{N}$ balance.

\section{Secondary factors}

Nutrition. Munro \& Chalmers (1945) demonstrated that protein deprivation prior to injury reduced or eliminated the anticipated increase in $\mathrm{N}$ excretion after fracture of the femur.

Gender. In an extensive study of eighty-three male and female patients undergoing a variety of operations, mainly thoracotomy, Halme et al. (1957) found that the endocrine response as measured by urinary 17 -hydroxycorticoid and adrenalin and noradrenalin excretion was considerably greater in male patients than in females in the first $3 \mathrm{~d}$ after operation. In both groups excretion of the hormones or metabolites did not return to normal until day 6 or 7 .

Age. The ability of the newborn to withstand surgery or injury has been extensively studied by Wilkinson (1976) and reviewed by Little (1975). Geriatric patients also show some differences in response.

Pre-existing pathology. It is obvious that diseases such as cancer or rheumatoid arthritis by increasing catabolism (Ballantyne et al. 1971) may modify the response to surgery. 


\section{Therapy}

Environmental temperature. It might be concluded from Elebute's (1974) observations of the increased nitrogen excretion following surgery at the high temperatures and humidity occurring in Nigeria that this factor should have been included under the second general heading (Secondary Factors). However, there is much evidence that increasing the environmental temperature to the thermoneutral zone (28- $32^{\circ}$ in man) has considerable therapeutic effect in reducing the loss of $\mathrm{N}$ in the urine after injury (Cuthbertson et al. 1972). This effect has been extensively utilized in the treatment of burned patients (Barr et al. 1968; Davies, 1970) for whom, without increasing the environmental temperature and hence reducing catabolism and the required energy intake, the outcome would have been fatal (Davies et al. 1977).

Other therapeutic agents. The therapeutic value of insulin accompanied by adequate energy (glucose) in reducing the extensive losses of $\mathbf{N}$ in the urine in patients who had been injured by burning has been shown by Hinton et al. (1971). Others, including ourselves, have observed that in patients with severe sepsis receiving parenteral nutrition therapy, intravenous insulin at appropriate dose stops glycosuria and rapidly reduces excessive $\mathrm{N}$ loss in the urine. The effect of antipyrin in reducing $\mathbf{N}$ excretion in fever has been mentioned above as has the effect of eliminating pain.

Endocrine changes. The endocrine changes after injury have been summarized by Allison (1974) and Wilmore (1976) and diagrammatically in reviews (Fleck, 1978, 1976b). The key urine changes have been mentioned above; 17hydroxycorticosteroids and adrenalin and noradrenalin increase very rapidly, peak about day 2 and return almost to normal between days 5 and 7. Plasma growth hormone and glucagon both rise rapidly and remain elevated for about $7 \mathrm{~d}$ after surgery. Plasma insulin, however, tends to be low during shock but rise during the flow phase (Allison et al. 1976). It is possible to relate these changes to metabolism after injury (see Allison, 1974; Fleck, 1976a, 1978; Wilmore, 1976). Catecholamines (Granitsas, 1960) and cortisol (Manchester, 1970) are recognized as having net catabolic effects on carcase protein and Millward et al. (1976) have confirmed that this is due to inhibition of muscle protein synthesis. The resultant effect is to mobilize amino acids from muscle and increase the supply to the liver. Glucagon is recognized to increase gluconeogenesis (Newsholme \& Start, 1973). The effects of growth hormone on protein metabolism are modified by insulin (Newsholme \& Start, 1973), so that insulin remains as the main protein anabolic hormone in adult man.

The metabolic response to injury or surgery is now seen as being due to the endocrine changes summarized previously, together with effects mediated by the central nervous system which mainly stimulate catecholamine secretion, and to other humoral factors such as endogenous pyrogen which leads to the acute phase response (see Fig. 1).

In summary therefore, from the known endocrine changes we would expect the following. In the ebb phase (and early flow phase) a net protein catabolism with 


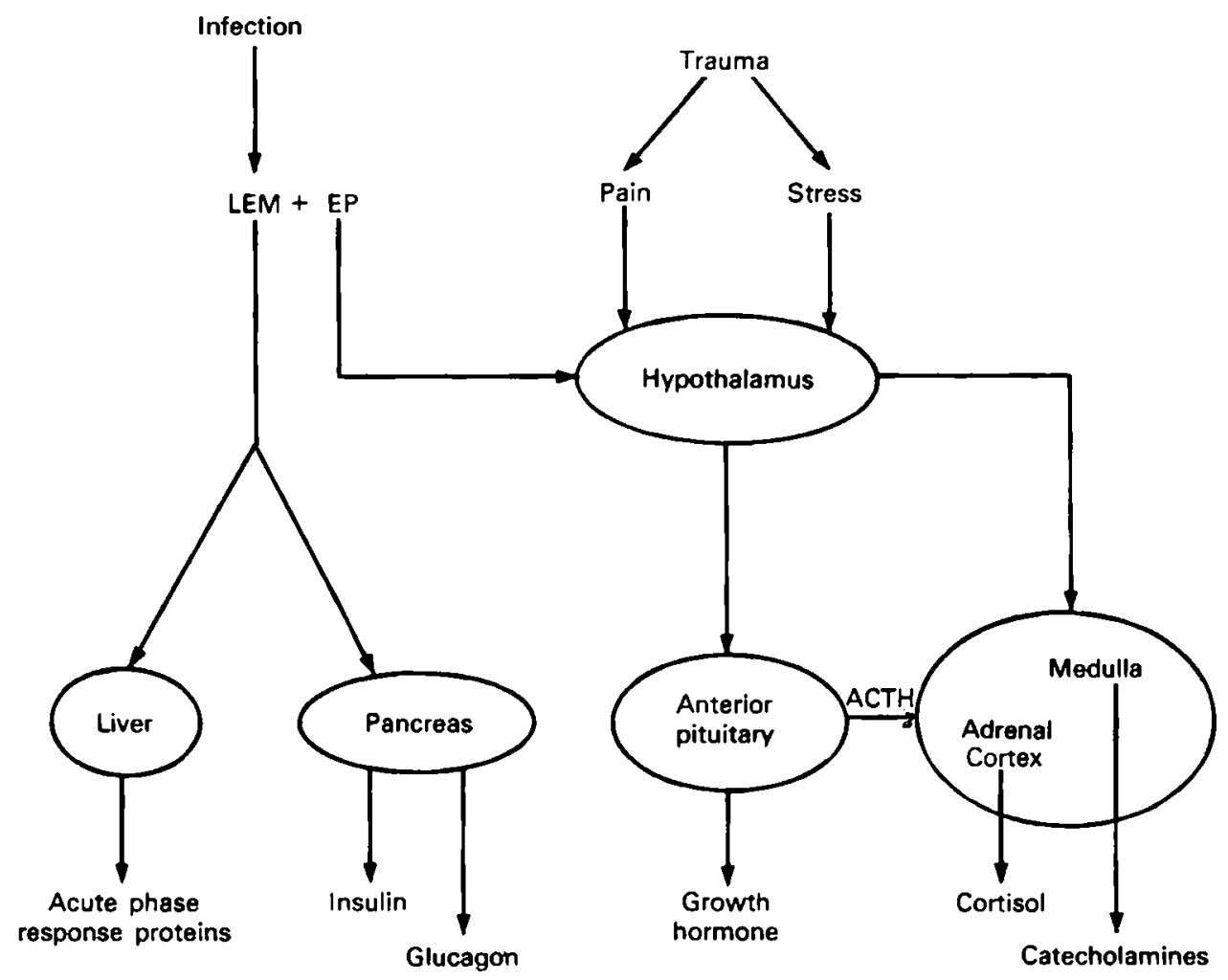

Fig. 1. Schematic representation of neuro-endocrine and humoral mechanisms in the response to injury. EP, endogenous pyrogen; LEM, leucocyte endogenous mediator; ACTH, adrenocorticotrophic hormone.

decreased synthesis. In the flow phase protein synthesis will tend to remain depressed until eating or input and insulin secretion return to normal. Thereafter the net synthesis rate of protein would increase so that for negative $\mathbf{N}$ balance to

Table $\mathrm{I}$. Changes in protein metabolism after injury or surgery

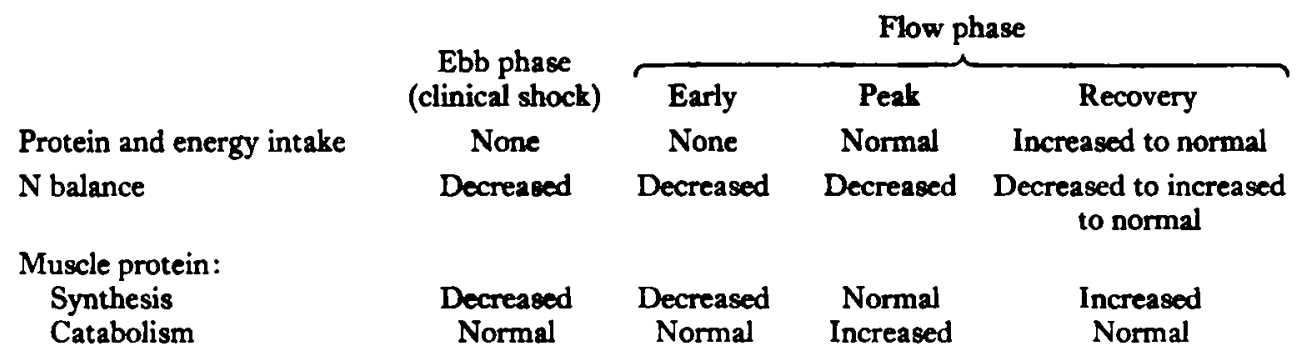


occur, breakdown must be increased to a greater extent than synthesis (see Table 1).

\section{Experimental observations}

In recent years several studies of protein metabolism after surgery have been carried out by Professor Waterlow and his associates (e.g. O'Keefe et al. 1974; Crane et al. 1977; Waterlow et al. 1977), using labelled amino acids, mainly $\left[{ }^{15} \mathrm{~N}\right.$ glycine or $\left[{ }^{14} \mathrm{C}\right]$ leucine. Most of these studies have been carried out in the first 24-48 $\mathrm{h}$ after surgery when the energy and protein intake is subnormal (e.g. Crane et al. 1977; O'Keefe et al. 1974). It is hardly surprising therefore that they found that protein synthesis was decreased at this time after surgery. Clague (unpublished observations) using a slightly different approach has found that later after surgery protein synthesis is increased and Powell-Tuck (unpublished observations) has found using a similar method to that of Waterlow et al. (1977) that when patients are given an adequate intravenous supply of amino acids and energy, protein synthesis does not fall after an operation. Stein et al. (1977) arrived at similar conclusions from their studies with experimental rats.

Several groups of workers have determined 3-methylhistidine excretion in the urine after injury and found it to be increased early and for several days (Williamson et al. 1977; Long, Jeevanandam et al. 1977; Gross et al. 1978). These studies were prompted by the observations of Young \& Munro (1978) that histidine is methylated in muscle after incorporation into protein and the methylated amino acid cannot be reincorporated into protein, so that its rate of excretion in the urine can give a measure of the rate of breakdown of carcase protein.

In summary therefore it appears that the predominant change in protein metabolism shortly after surgery (or injury) is a decrease in protein synthesis resulting in net negative $\mathrm{N}$ balance. Later it appears that carcase protein catabolism increases to a greater extent than synthesis, which although it may have become greater than normal, is insufficient to balance breakdown, so that net negative $\mathrm{N}$ balance occurs. Similar changes occur in sepsis (Long, Jeevanandam et al. 1977).

\section{The acute phase response}

In experimental investigations of the acute phase response induced by infection with sandfly fever, Wannamacher et al. (1975) observed that shortly after significant quantities of the infecting agent occur in the animal body the polymorphonuclear leucocytes, macrophages etc. produce the polypeptides leucocyte endogenous mediator (LEM) or endogenous pyrogen (EP). In the presence of prostaglandins these substances produce several systemic and central effects. For example, the influence on the hypothalamus leads to increased production of growth hormone and ACTH by the pituitary and consequent increased cortisol secretion. Similarly, insulin and glucagon secretion are stimulated. LEM has a direct effect on the liver to stimulate increased synthesis of 
the group of plasma proteins known as the acute phase reactants. These include fibrinogen, $\alpha$; -acid glycoprotein, $\alpha$; -antitrypsin, and C-reactive protein (CRP). In parallel with increased concentration of these proteins in plasma, the concentration of some proteins falls. Examples include albumin, transferrin and the lipoproteins (see Fleck, 1976a,b, 1978).

It is important to note that the synthesis and catabolic rates of some plasma proteins are not the main determinants of the concentration in plasma. In the case of albumin for example the fractional synthesis (or catabolic) rate is $0.1 / \mathrm{d}$ (i.e. $10 \%$ of the intravascular space pool is synthesized and broken down /d). In contrast, the rate of escape to the extravascular pool is normally about 7-10 times the fractional synthesis rate. Another factor is that the extravascular pool of albumin is usually about $1 \cdot 3^{-1 \cdot 4}$ times the intravascular pool (see Schultz \& Heremans, I966). Thus, the former may act as a 'buffer' maintaining the intravascular pool during protein depletion.

However, if capillary permeability is increased or lymphatic return reduced, the extravascular pool will increase rapidly at the expense of the plasma protein, the concentration of which will fall and take some time to recover owing to the relatively low synthesis rate. It is likely that this (plus of course some direct losses) is the explanation for the rapid fall in albumin concentration after injury (see Ballantyne \& Fleck, 1973).

There is evidence from many sources that a low concentration of albumin in plasma is likely to be due to (in descending order of importance): (a) excess fluid (or fluid retention); (b) losses (e.g. of blood); (c) increased capillary permeability (e.g. in burns, sepsis or shock); (d) increased catabolism (e.g. rheumatoid arthritis, injury); (e) decreased synthesis (e.g. protein depletion).

It follows that the concentration of albumin in plasma in acutely ill patients cannot be used as an indicator either of the patient's nutritional status or of carcase protein metabolism.

Research support from MRC and SHERT is gratefully acknowledged; also helpful discussion with numerous colleagues including Sir David Cuthbertson, Dr J. W. L. Davies, Dr G. S. Fell, Mr M. Glague (Newcastle) and Dr J. PowellTuck (St. Mark's Hospital, London); especially MG and J.P.-T. for permission to refer to their as yet unpublished results.

\section{REFERENCE8}

Allison, S. P. (1974). Br. F. hosp. Med. 11, 860.

Allison, S. P., Hinton, P., Woolfson, A. \& Heatley, T. V. C. (1976). In Metabolism Response to Injury. [A. W. Wilkinson and Sir David Cuthbertson, editors]. p. 113. Tunbridge Wells: Pitman Medical.

Almqvist \& Wiksell (I916). J. Berzelius' Lettres II: 2, V. Correspondance entre Berzelius \& G. J. Mulder. Uppsala 1916. 104.

Ballantyne, F. C. \& Fleck, A. (1973). Clinica. chim. Acta 46, 139.

Ballantyne, F. C., Fleck, A. \& Dick, W. C. (1971). Ann. rheum. dis. 30, 265.

Barr, P. O., Birke, G., Liljedahl, S. O. \& Plantin, L. O. (1968). Lancet i, 164.

Boussingault, M. (1839a). Annls Chim. Phys. 17, 113 . 
Boussingault, M. (1839b). Annls Chim. Phys. 71, 128.

Crane, C. W., Picou, D., Smith, R. \& Waterlow, J. C. (1977). Br. J. Surg. 64, 129.

Cuthbertson, D. P., (1932). Q. fl Med. 25 (New Series 1), 233.

Cuthbertson, D. P., (1942). Lancet i, 433 .

Cuthbertson, D. P., Fell, G. S., Smith, C. M. \& Tilstone, W. J. (1972). Br. F. Surg. 59, 925.

Davidson, E. C. (1926). Archs Surg., Lond. 13, 262.

Davies, J. W. L. (1970). F. clin. Path. 23, suppl. (Roy. Coll. Path.) $4,56$.

Davies, J. W. L., Lamke, L. O. \& Liljedahl, S. O. (1977). Acta Chirurg Scand. Suppl. 468, 25.

Elebute, E. A. (1974). Br. F. Surg. 6r, 60.

Fleck, A. (1976a). In Metabolism and the Response to Injury. [A. W. Wilkinson and Sir David Cuthbertson, editors]. p. 229. Tunbridge Wells: Pitman Medical.

Fleck, A. (1976b). In Shock, Clinical and Experimental Aspects. Monographs in Anaesthesiology, vol. 4, ch. 4, p. 57. [I. McA. Ledingham, editor]. Oxford: Excerpta Medica.

Fleck, A. (1978). In famieson \& Kay's Textbook of Surgical Physiology. ch. 4, p. 42. [I. McA. Ledingham and C. Mackay, editors]. Edinburgh: Churchill Livingstone.

Fleck, A., Gedeon, G., Rowe, D., Caine, S., Crossan, J. \& Richards, J. (1979). Proc. Scot. Soc. exp. Med. 7. (In the Press).

Granitsas, A. N. (1960). Am. F. Physiol. 198, 603.

Gross, E., Holbrook, I. B. \& Irving, M. H. (1978). Br. F. Surg. 65, 663.

Halme, A., Pekkarin, A. \& Turunen, M. (1957). Acta endocr. Suppl. 32, 5.

Hinton, P., Allison, S. P., Littlejohn, S. \& Lloyd, J. (I97I). Lancet i, 767.

Kinney, J. M., Duke, J. H. Jr., Long, C. L. \& Gump, F. E. (I970). F. clin. Path. 23, suppl. (Roy. Coll. Path.) 4, 56.

Little, R. A. (1975). Br. F. Surg. 62, 868.

Long, C. L., Jeevanandam, M., Kim, B. M. \& Kinney, J. M. (1977). Am. F. clin. Nutr. 30, 1340.

Long, C. L., Schiller, W. R., Blakemore, W. S., Geiger, J. W., O'Dell, M. \& Henderson, K. (1977). Am. J. clin. Nutr. 30, 1349.

Manchester, K. L. (1970). In Mammalian Protein Metabolism, vol. 4, ch. 33, p. 229. [H. N. Munro, editor]. London: Academic Press.

Masek, J. \& Horky, J. (1957). Reo. Czech. Med. III, 42.

Millward, D. J., Garlick, P. J., Nnanyelugo, D. O. \& Waterlow, J. C. (1976). Biochem. F. 156, I85.

Moore, F. D. (1953). Ann. Surg. 137, 289.

Moore, F. D., Steenburg, R. W., Ball, M. R., Wilson, G. M. \& Myrden, J. A. (1955). Ann. Surg. I4I, 145 .

Mulder, G. J. (1838). Bull. Sci. Phy. Nat. Neederland, p. 104.

Muller, F. (1884). Zentbl. Klin. Med. 5, 569 .

Munro, H. N. (1964). In Mammalian Protein Metabolism. ch. I, p. I. [H. N. Munro and J. B. Allison, editors]. London: Academic Press.

Munro, H. N. \& Chalmers, M. I. (1945). Br. J. exp. Path. 26, 396.

Newsholme, E. A. \& Start, C. (1973). Regulation in Metabolism. London: John Wiley \& Sons.

O'Keefe, S. J. D., Sender, P. M. \& James, W. P. T. (1974). Lancet ii, 1035.

Sassetzky, N. A. (1883). Arkh. Patol. 94, 485.

Schultz, H. E. \& Heremans, J. F. (1966). Molecular Biology of human proteins with special reference to plasma proteins. I. Nature and metabolism of extracellular proteins. Amsterdam \& London: Elsevier Publishing Co.

Shaffer, P. A., Coleman, W. (Ig09). Archs intern. Med. 4, 538.

Stein, T. P., Leskiw, M. J., Wallace, H. W. \& Oram-Smith, J. C. (1977). Am. F. Physiol. 233, $\mathrm{E}_{348}$.

Stoner, H. B. (1970). F. clin. Path. 23, suppl. (Roy. Coll. Path.) $4,47$.

Vogel, A. (1 854). Z. ration Medicin Neu rolge 4, 362 .

Wannemacher, R. Jr., Pekarek, R. S., Thompson, W. L., Curnow, R. T., Beall, F. A., Zenser, T. V., De Rubertis, F. R. \& Beisel, W. R. (1975). Endocrinology 96, 651.

Waterlow, J. C., Golden, M. \& Picou, D. (1977). Am. F. clin. Nutr. 30, 1333.

Wertheimer, Fabre \& Clogne, R. (1919). Bull. Mem. Soc. Chir. Paris 45, 8.

Wilkinson, A. W. (1976). In Metabolism and the Response to Injury. p. 35. [A. W. Wilkinson and Sir David Cuthbertson, editors]. Bath: Pitman Medical Publishing.

Williamson, D. H., Farrell, R., Kerr, A. \& Smith, R. (1977). Clin. Sci. Mol. Med. 52, 527. 
Wilmore, D. W. (1976). Surg. Clins N. Am. 56, 999.

Young, V. R. \& Munro, H. N. (1978). Fedn Proc. Fedn Am. Socs exp. Biol. 37, 229 I. 